\title{
PROSECUTION OF MONEY LAUNDERING OF PROCEEDS OF CORRUPTION BY ANTI-CORRUPTION COMMISSION (KPK)*
}

\author{
Muhammad Fatahillah Akbar** \\ Criminal Law Department, Faculty of Law, Universitas Gadjah Mada, Yogyakarta \\ Jalan Sosio Yustisia 1, Bulaksumur, Sleman D.I. Yogyakarta 55281
}

\begin{abstract}
As extra ordinary crime, corruption which may be done in several ways is hard to be eradicated. One of the ways is money laundering. The problem which arises is that KPK has no authority to prosecute money laundering of corruption proceed. This research aims to explore the authority to prosecute money laundering of corruption proceed based on existing legislations and to also provide the reform of law regarding to that issue. The research shows that there is no regulation which authorizes KPK to prosecute money laundering. To cope with that problem, the reform of laws is necessary by: First, combining the regulation of money laundering and corruption in one legislation; and Second, authorizing KPK to prosecute money laundering of corruption proceed by putting the authority in a legislation.
\end{abstract}

Keywords: corruption, money laundering, prosecution, KPK.

\section{Intisari}

Sebagai extra ordinary crime, korupsi dengan berbagai modus operandi tidak mudah diberantas. Salah satu modus operandi yang kompleks adalah TPPU. Permasalahan yang timbul dalam TPPU hasil tindak pidana korupsi adalah dimana KPK tidak diberikan kewenangan melakukan penuntutan terhadap TPPU hasil korupsi. Penelitian ini bertujuan untuk mengeksplorasi kewenangan penuntutan terhadap perkara TPPU hasil korupsi dalam hukum positif dan memberikan reformulasi pengaturan terhadap hal tersebut. Hasil penelitian menunjukan bahwa terdapat kekosongan hukum dalam penegakan hukum pada perkara TPPU hasil tindak pidana korupsi yang ditangani KPK. Untuk mengatasi permasalahan tersebut perlu reformulasi peraturan dengan: (1) mengatur secara tersendiri TPPU dalam UU PTPK; dan (2) memberikan kewenangan KPK untuk melakukan penuntutan terhadap perkara TPPU hasil tindak pidana korupsi.

Kata Kunci: korupsi, TPPU, penuntutan, KPK.

\section{Pokok Muatan}

A. Background 323

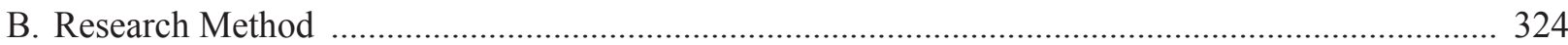

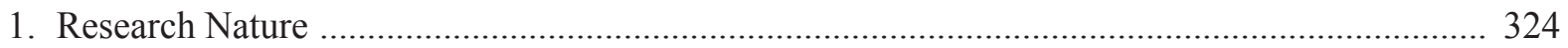

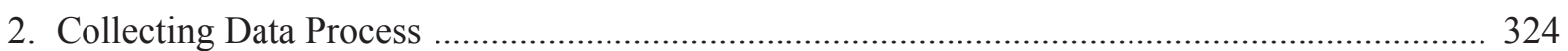

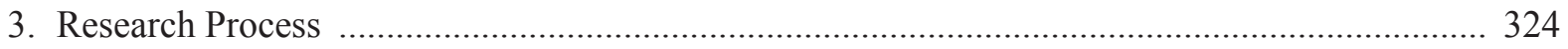

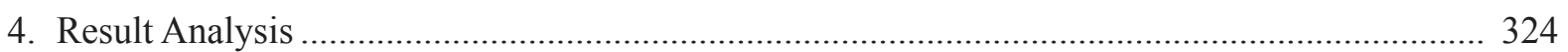

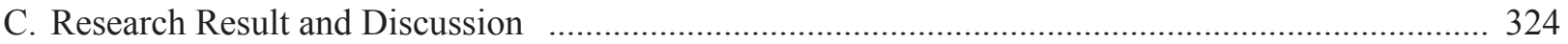

1. The Prosecution of Money Laundering in Corruption ............................................................. 324

2. The Reform of Legislation regarding The Prosecution on Money Laundering in Corruption .... 329

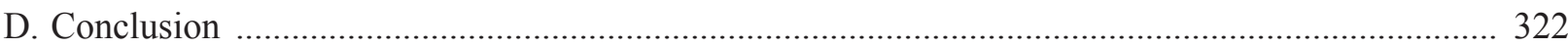

Research Result funded by “Unit Penelitian dan Pengabdian Masyarakat” FH UGM Year 2014.

Correspondence address: muhfatahillahakbar@yahoo.com. 


\section{A. Background}

Corruption in Indonesia has been developed more and more associated with several complex modus operandi. One of complex ways to commit corruption is by hiding, covering, and cleaning the proceed of corruption by money laundering. The proceeds of corruption will be vague and it will be difficult to return it to the state. Therefore, the law enforcement of money laundering of corruption proceeds shall be strongly established.

However, the eradication of that crime is complex. In eradicating corruption, a commission called Anti-Corruption Commission (KPK) is established. ${ }^{1} \mathrm{KPK}$ is not the only institution which may deal with corruption. The other institutions are Police Force and Prosecutors under General Attorney. ${ }^{2}$ Differently with both institutions, KPK has several specialities, such as the authority to conduct an investigation and prosecution in corruption cases. KPK may conduct those authorities only for particular types of cases. ${ }^{3}$

The weakness of the regulation on KPK written in the Law Number 30 of 2002 on KPK (the Law on KPK) is the absence of the authority of KPK to prosecute money laundering. Specifically, the formal regulation on money laundering can be found on The Law Number 8 of 2010 on Eradication of Money Laundering (the Law on Money Laundering). The law states that the investigator of money laundering is the investigator of the predicate crimes. ${ }^{4}$ Hence, KPK has the authority to investigate money laundering of proceed of corruption.

However, the Law on Money Laundering does not regulate the prosecution authority. If the special criminal law does not regulate a thing, it shall refer to the Criminal Procedural Code as regulated by the Law No. 8 of 1981 on Criminal Procedural (Criminal Procedural Code). Criminal Procedural Code regulates that the prosecution is the public prosecutors' authority. ${ }^{5}$ It can be stated that in money laundering, Public prosecutors can be the prosecutor, although the investigators can be from various institutions, such as National Bureau of Narcotics (BNN) on narcotics or Police force on general crimes. It can be complex for the case investigated by KPK because this commision has the authority to continue the investigation by conducting the prosecution for the case. The authority to prosecute money laundering by KPK cannot be found in any legislation. Conversely, the practice of the prosecution of money laundering by KPK has been conducted several times. The case of Lutfi Hasan Ishaaq as the former president of a big political party is one of the best examples to show the practice. In that case, KPK conducted the prosecution on money laundering case. However, the judges have dissenting opinion regarding to the authority. ${ }^{6}$ It happened because there is the absence of the regulation. In terms of this, Yunus Hussein as the former leader of Financial Supervisor states. Since, the criminal procedural law is based on legality principles, so any authority, including the prosecution, shall be regulated in legislation. However, the practice requires the authority of $\mathrm{KPK}$. Hence, this is a big problem in corruption eradication system.

Based on the problems, there are legal problems regarding to the authority. Therefore, this research was conducted to examine how the criminal justice system works in money laundering of corruption proceed. The legal problems of this case are: Firstly, how is the regulation of the

\footnotetext{
Art. 11 of the Law No. 30 of 2002 on The Anti-Corruption Commission (State Gazzete of Indonesian Republic of 2002 No. 137, Supplement to State Gazzete No. 4250).

Art. 7 of the Law No. 30 of 2002 on The Anti-Corruption Commission(State Gazzete of Indonesian Republic of 2002 No. 137, Supplement to State Gazzete No. 4250).

Art. 11 of the Law No. 30 of 2002 on The Anti-Corruption Commission (State Gazzete of Indonesian Republic of 2002 No. 137, Supplement to State Gazzete No. 4250).

Art. 74 of the Law No. 8 of 2010 on Prevention and Eradication of Money Laundering (State Gazzete of 2010 No. 122,Supplement to State Gazzete No. 5164).

Art. 1 (7) of the Law No. 8 of 1981 on Criminal Procedural Law (State Gazzete of Indonesian Republic of 1981 No. 76).

Verdict of Central Jakarta's District Court No. 38/Pid.Sus/TPK/2013/PN.Jkt.Pst on first level adjudication on the accused Lutfi Hasan Ishaaq, $9^{\text {th }}$ December 2013.
} 
Prosecution of Money laundering as corruption proceed in Indonesia Criminal Justice System?; and Secondly, how is the viable regulation regarding to the KPK's authority to prosecute money laundering?

\section{B. Research Method \\ 1. Research Nature}

This research nature is normative research. The normative research is done to collect secondary data, namely primary, secondary, and tertiary legal materials including books, journals, legislations, and court decisions. Those materials are related to corruption, money laundering and KPK. In this matter, Primary legal materials are legislations and court decisions which are related to the legal problems of the research. Besides that, secondary legal materials are books, journals, papers, and other secondary materials related to the purpose of the research. While, the tertiary legal materials are supporting litteraturs, such as dictionary.

\section{Collecting Data Process}

The process to collect data in this research is by conducting the library research on legislations, judicial binding verdicts, books, reliable journals, research reports, and other relevant materials regarding to prosecution authority, money laundering, corruption, anti-corruption commission, and Indonesian law system. In collecting data, all necessary information related to research is summarized and noted to be analysed further and confronted with another relevant materials so that the conclusion will be more scientifically reliable. To be more accountable, all data will be listed in reference list using the appropriate way of citation.

\section{Research Process}

In this research the basis is to answer the legal problems. To answer the first legal problems, the deep analysis on criminal justice system of corruption shall be done first. After that step, the prosecution on money laundering generally shall be examined. Then, the prosecution on money laundering by KPK will be explained. The conclusion of the first legal problem is whether the KPK has the authority and how the condition is. To answer this problem, all related legislations from the Law to the implementing legislations and also court decisions shall be explored. It shall be supported by literatures.

The second legal problem will be answered by addressing the problems found in the first analysis. To answer how the solution is, the legal comparison between Indonesian corruption eradication system and other countries shall be elaborated. The other thing is that the elaboration of UNCAC shall be examined regarding to money laundering. The conclusion shall be how to solve the problems regarding to the prosecution authority of KPK.

\section{Result Analysis}

Since using the normative research, the data in this research is analysed using the qualitativedescriptive method, which conducts the analysis using the three aspects, namely classification, comparision, and connection. In other words, the qualitative method is not only to reveal the accountable information, but also to understand that information. Therefore, the data collected using the library research will be further analysed by the qualitative method to answer the research question. Specifically in this research, the authority of KPK to prosecute money laundering will be answered by comprehensive analysis on legislation and relevant theories. The comparison between countries and the theories will be used to formulate the best solution.

\section{Research Result and Discussion \\ 1. The Prosecution of Money Laundering in Corruption}

a. Criminal Justice System in Corruption

Remington and Ohlin as cited by Romli Atmasasmita state that criminal justice system can be seen from system approach as the combination of legislation, administrative conducts, and social behaviours. ${ }^{7}$ Moreover, 
Mardjono Reksodiputro explaines criminal justice system as the system to control crimes involving police forces, prosecutors, courts, and correctional institutions in establishing integrated criminal justice system. ${ }^{8}$ Furthermore, Mardjono Reksodiputro as cited by Romli Atmasasmita examines that the aim of criminal justice system can be formulated as these puposes, namely: ${ }^{9}$ to prevent the society to be the victims; to solve criminal cases to show that the justice can be enforced; and to establish the influence on perpetrator to not conduct crimes anymore.

Muladi emphasizes that criminal justice system is the synchronization of structural, substantial, and cultural aspects. ${ }^{10}$ The Concept used by Lawrence M. Friedman ${ }^{11}$ to elaborate the law system is by analysing the substantial, structural, and cultural law. Criminal justice system can be seen as broader than criminal procedural law which merely contains on substance of law, while the system also covers culture and structure of laws. In terms of this, it is clear that laws cannot merely be seen as the legislations, but also how to implement the legislation.

To add, Jimly Assidiqie states that criminal justice system without substantive law is useless, but without procedural law, it will abuse and may create the "judicial tyrany" "I2. If it is seen from the substance, criminal justice system is procedural law and it regulates how to properly proceed the criminal cases. Historically, abuse of authority in criminal proceeding is common in primitive society. Therefore, the criminal justice system in modern era is established to provide a fair trial.

Before analysing the justice system on money laundering, it is important to analyse the justice system on corruption. It is because the money laundering is always related to the predicate crimes. It can be seen that in active and passive money laundering "predicate crimes" is always the important element. ${ }^{13}$ Besides that, corruption is one of the predicate crimes stated in Article 2 of the Law on Money Laundering. ${ }^{14}$

In discussing the Procedural law, it is regulated that the investigator of money laundering is the investigator of predicate crimes. ${ }^{15}$ In dealing with corruption case, there are several specificities of the corruption case. One of the specificities is that corruption shall be more primarily solved than other cases. ${ }^{16}$ Based on that discussion, it can be stated that the proceeding of corruption case is crucial. There are three institutions which may investigate corruption case, namely Indonesian Police Force (Polri), General Attorney, and KPK.

Basically, Polri has authority to investigate and inquire all crimes. ${ }^{17}$ Hence, Polri has the authority to inquire and investigate corruption because no legislation has taken that authority. To analyse further, it is important to explain what inquiry and investigation are. Inquiry, according to Art

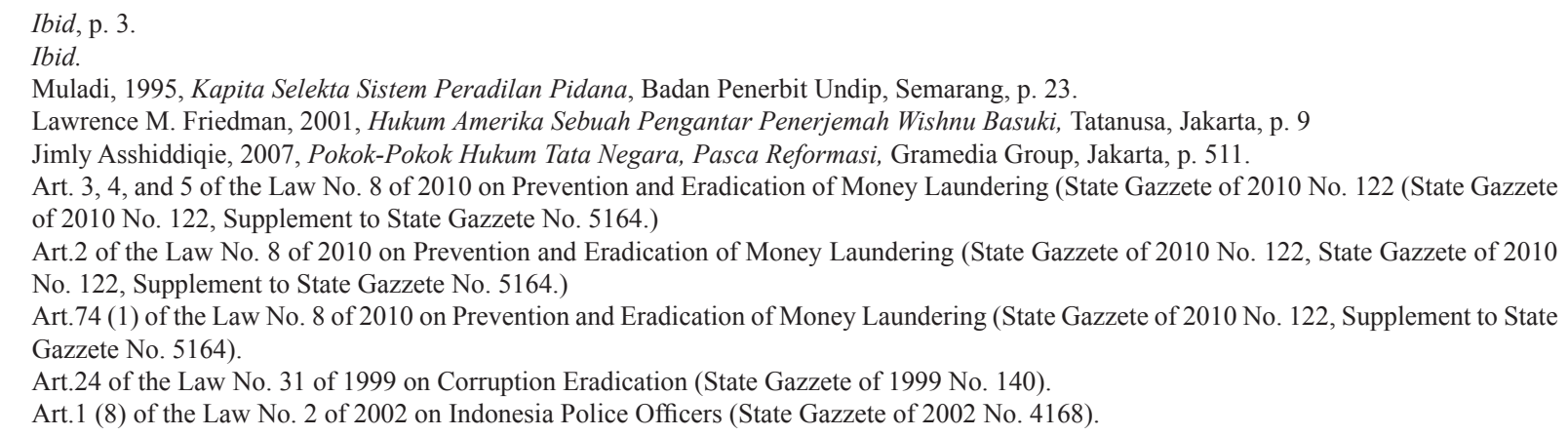


1 ph (5) of KUHAP, is a series of act to determine whether an event is a criminal event or not. ${ }^{18}$ Furthermore, Investigation is a series of an act which means are regulated by the Law to collect evidences, enlighten the case, and locate the suspect. ${ }^{19}$ That series of act is committed by the investigator, namely Indonesian Police Force and Public Servant Investigators authorized by legislations. ${ }^{20}$ Basically, Polri still has the authority to inquire and investigate corruption under the coordination of KPK. Polri also has responsibility to report the Letter of the Beginning of the Investigation (SPDP) to inform KPK that Polri is dealing with corruption case. ${ }^{21}$

General Attorney is another institution which may conduct investigation on corruption case. Actually, that authority is not specifically given by legislation. Article 27 of the Law on Corruption rules that if the corruption case is complex, the investigation team can be established under the coordination of General Attorney. ${ }^{22}$ Besides that, the Law on KPK also regulates that investigation conducted by Polri and General Attorney is under the coordination of KPK. ${ }^{23}$ By the main regulation on General Attorney on Corruption Case, it can be concluded that General Attorney may conduct the investigation on corruption cases.

After the discussion of those investigators, the primary law enforcement in corruption case is KPK which has the function to supervise and coordinate in every corruption case which fulfils one of the requirements stated by Article 11 of the Law on KPK, which is:

In conducting the duty stated in Article 6 (c), KPK has authority to inquire, investigate, and prosecute corruption which a. involves law enforcement, public officials, and others related to law enforcement and public officials; b. involves public interest; and/or c. related to the loss of the state as much as Rp. $1.000 .000 .000,00$ or more. ${ }^{24}$

It can be concluded, KPK has the biggest authority in corruption eradication. Although Polri and General Attorney have the authority on corruption, but it is limited by KPK's authority. Moreover, KPK even can takeover cases conducted by Polri or General Attorney. ${ }^{25}$

It can be seen that KPK may conduct investigation and prosecution in one institution. It is clearly different with functional differentiation theory ruled by KUHAP where investigation and prosecution are conducted by different institutions. ${ }^{26}$ Based on Article 11 of the Law on KPK, KPK may conduct investigation and prosecution. ${ }^{27}$ Implicitly, it can be interpreted that investigation done by KPK shall be continued by KPK itself in Prosecution. There is no chance that Prosecution can be conducted by another institution, if the investigation is done by KPK. This argument is strengthened by the authority to takeover

\footnotetext{
Art.1 (5) of the Law No.8 of 1981 on Criminal Law Procedure (State Gazzete of 1982 No. 76, Supplement to State Gazzete No. 3209).

Art.1 (2) of the Law No. 8 of 1981 on Criminal Procedural Law (State Gazzete of Indonesia of 1981 No. 76).

Art.1 (1) of the Law No. 8 of 1981 on Criminal Procedural Law (State Gazzete of Indonesia of 1981 No. 76).

Art. 7 of the Law No. 30 of 2002 on The Anti-Corruption Commission (State Gazzete of Indonesian Republic of 2002 No. 137, Supplement to State Gazzete No. 4250).

22 Art. 27 of the Law No. 31 of 1999 on Corruption Eradication (State Gazzete of Indonesian Republic of 1999 No. 140, Supplement to State Gazzete No. 3874).

23 Art.7 of the Law No. 30 of 2002 on The Anti-Corruption Commission (State Gazzete of Indonesian Republic of 2002 No. 137, Supplement to State Gazzete No. 4250).

24 Art.11 of the Law No. 46 of 2009 on Corruption Court (State Gazzete of Indonesia of 2009 No. 155, Supplement to State Gazzete No. 5074).

25 Art.10 of the Law No. 30 of 2002 on The Anti-Corruption Commission (State Gazzete of Indonesian Republic of 2002 No. 137, Supplement to State Gazzete No. 4250).

Yahya Harahap, Op.cit., p. 47.

27 Art.11 of the Law No. 30 of 2002 on The Anti-Corruption Commission (State Gazzete of Indonesian Republic of 2002 No. 137, Supplement to State Gazzete No. 4250).
} 
cases. ${ }^{28}$ In that authority, it is seen the power of KPK to prosecute is strong.

However, that authority raises the problem with General Attorney. ${ }^{29}$ The position of General Attorney based on the Law Number 16 of 2004 on Indonesian General Attorney is in the executive which means that General Attorney is dependent. ${ }^{30}$ By the development of crimes, the authority of Prosecutors are limited either in investigation or prosecution. ${ }^{31}$ The establishment of KPK has the big influence of the duty of Prosecutors. Prosecutors should be dominus litis (the controller of the case) and principle of een on deelbaar (prosecutors are single and cannot be separated). ${ }^{32}$ KPK makes that Public Prosecutor is not the only institution which can conduct the prosecution. KPK is also dominus litis in corruption case.

Besides prosecution, adjudication of corruption cases regulated by the Law on Corruption shall be only conducted by corruption court. ${ }^{33}$ It is strictly regulated by the Law on Corruption Court which states that Corruption Court is the only Court which may examine and adjudicate corruption. ${ }^{34}$

The structure of corruption court is under the scope of General Court. ${ }^{35}$ Corruption court shall examined and adjudicate in 90 (ninety) working days starting from the delivery of the cases to corruption court. ${ }^{36}$ The examination is conducted by the Board of 5 (five) judges which contain 2 (two) carrier Judges and 3 (three) ad-hoc judges. ${ }^{37}$

Based on the analysis above, it can be concluded that corruption eradication system has been comprehensively established from the inquiry to examination at corruption court. Inquiry and investigation may be conducted by KPK, Polri, and General Attorney. The Prosecution may be conducted by KPK and General Attorney. Then, the Adjudication can only be conducted by Corruption Court.

\section{b. Criminal Justice System on Money Laundering in Corruption}

The discussion on the criminal justice system on corruption is strongly related to the criminal justice system on money laundering in corruption. Before conducting the discussion on the procedural law, it is important to examine the substantive law on money laundering in corruption. Basically, The Law on Money Laundering focuses on two types of crimes, namely active and passive money laundering. Active money laundering is the crime which places, transfer, or other action of the fund which is proceed of predicate crimes with the purpose to disguise the source of the fund. ${ }^{38}$ While, passive money laundering is the action to receive that fund..$^{39}$ The crucial matter of active and passive money laundering is that money laundering is a subsidiary crime which always requires the predicate crime.

\footnotetext{
Art. 8(2) of the Law No. 30 of 2002 on The Anti-Corruption Commission (State Gazzete of Indonesian Republic of 2002 No. 137).

29 Pusat Litbang Kejaksaan Agung R.I, "Studi tentang Implementasi Kekuasaan Penuntutan Di Negara Hukum Indonesia”, http://www.kejaksaan. go.id/unit kejaksaan.php?idu=28\&idsu=35\&id=54, accessed 30 October 2014.

Ibid.

Ibid.

Ibid.

Art.53 and Art.6 of the Law No. 30 of 2002 on The Anti-Corruption Commission (State Gazzete of Indonesian Republic of 2002 No. 137 , Supplement to State Gazzete No. 4250).

34 Art.5 of the Law No. 46 of 2009 on Corruption Court (State Gazzete of Indonesia of 2009 No. 155, Supplement to State Gazzete No. 5074).

35 Art.54 (1) of the Law No. 46 of 2009 on Corruption Court (State Gazzete of Indonesia of 2009 No. 155, Supplement to State Gazzete No. 5074).

36 Art.58 (1) of the Law No. 46 of 2009 on Corruption Court (State Gazzete of Indonesia of 2009 No. 155, Supplement to State Gazzete No. 5074).

37 Art.58 (2) of the Law No. 46 of 2009 on Corruption Court (State Gazzete of Indonesia of 2009 No. 155, Supplement to State Gazzete No. 5074).

38 Art. 3 of the Law No. 8 of 2010 on Prevention and Eradication of Money Laundering (State Gazzete of 2010 No. 122 , Supplement to State Gazzete No. 5164).

39 Art. 5 of the Law No. 8 of 2010 on Prevention and Eradication of Money Laundering (State Gazzete of 2010 No. 122 , Supplement to State Gazzete No. 5164)
} 
Article 2 of the Law on Money Laundering provides the list of predicate crimes. ${ }^{40}$

As mentioned above, the substantive law is particularly related to the procedural law. The predicate crimes listed in Article 2 of the Law influence the procedural law. It can be seen that in Article 74 paragraph (1) of the Law states that the investigator of the Predicate Crime is the investigator of money laundering. ${ }^{41}$ It can be simply stated that the investigator of money laundering can be Polri, Prosecutors, and KPK. Moreover, KPK has the authority to investigate corruption cases based on Article 11 of the Law on KPK.

However, the Law on Money Laundering does not provide regulation regarding the authority of KPK to Prosecute Money Laundering. It is implied in several articles on the Law on Money Laundering. Article 72 of the Law states that investigator, prosecutors, and judges can request a testimony from the reporter. ${ }^{42}$ To request that, the investigator shall have the signature of the commissioner of Polri, if the investigator is conducted by the Polri ${ }^{43}$ and the signature of the Chief of a commission, if the investigation is conducted by the commission. ${ }^{44}$ It can be interpreted that KPK is one of the commissions that can conduct the investigations stated in Article 72. However, in the prosecution, the Law only recognizes the General Attorney and the Chief of the High Prosecutor as the chief of the institution which is responsible to prosecute money laundering cases. ${ }^{45}$ It implies that the prosecution may only be conducted by the public prosecutor, not other institutions.

Besides that request, the relationship between the law enforcement in money laundering and the Centre of Report and Analysis on Financial Transaction (PPATK) can be examined to discuss the authority to prosecute. Article 90 paragraph (1) of the Law on Money laundering obligates every law enforcement to cooperate with PPATK in prevention and eradication of money laundering. In Article 90 paragraph (3) of the Law, it is listed the law enforcement that shall cooperate. ${ }^{46}$ In terms of this, KPK is only a commission that can involve in investigation. ${ }^{47}$ In this matter, KPK is not mentioned to conduct a prosecution. It can be stated that there is no supporting argument based on the Law on Money Laundering that provides the KPK the authority to prosecute.

However, in the Law on KPK, Article 53 of the Law provides that the authority to prosecute in corruption court is only authorized to KPK. However, that article was rejected by the Constitutional Court due to several legal reasons. While, that article implies that KPK has important authority to prosecute in Corruption Court. This authority is strengthened by the Article 5 of the Law on Corruption Court which states that the corruption court is the only court which can adjudicate corruption cases. ${ }^{48}$ Then corruption case is defined by Article 6 of the Law which

Art. 2 of the Law No. 8 of 2010 on Prevention and Eradication of Money Laundering (State Gazzete of 2010 No. 122).

Art.74 (1) of the Law No. 8 of 2010 on Prevention and Eradication of Money Laundering (State Gazzete of 2010 No. 122).

Art.72 (1) of the Law No. 8 of 2010 on Prevention and Eradication of Money Laundering (State Gazzete of 2010 No. 122, Supplement to State Gazzete No.5164).

43 Art.72 (5) of the Law No. 8 of 2010 on Prevention and Eradication of Money Laundering (State Gazzete of 2010 No. 122, Supplement to State Gazzete No.5164).

44 Art.72 (5) of the Law No. 8 of 2010 on Prevention and Eradication of Money Laundering (State Gazzete of 2010 No. 122, Supplement to State Gazzete No.5164)

45 Art.72 (5) (c) of the Law No. 8 of 2010 on Prevention and Eradication of Money Laundering (State Gazzete of 2010 No. 122 , Supplement to State Gazzete No.5164).

46 Art.90 (3) of the Law No. 8 of 2010 on Prevention and Eradication of Money Laundering (State Gazzete of 2010 No. 122 , Supplement to State Gazzete No.5164).

47 Art.90 (3) and (4) of the Law No. 8 of 2010 on Prevention and Eradication of Money Laundering (State Gazzete of 2010 No. 122, Supplement to State Gazzete No.5164).

48 Art.5 of the Law No. 46 of 2009 on Corruption Court (State Gazzete of Indonesia of 2009 No. 155). 
states that corruption cases is corruption, money laundering in corruption, and other action which is labelled as corruption. ${ }^{49}$ It can be seen clearly that money laundering in corruption is the authority of corruption court. It can be stated whoever the investigators and the prosecutors, the court is only corruption court. However, there is still no regulation on KPK's prosecution on money laundering.

From those discussion, the main problem in corruption eradication system is the absence of the regulation on the authority of KPK to prosecute. In investigation based on Article 74 paragraph (1), KPK may conduct the investigation on money laundering. Moreover, Corruption court also has the authority to adjudicate money laundering in corruption. However, in those legislations, the KPK is not authorized to conduct prosecution on money laundering in corruption. To deeply examine this situation, the theory and practice regarding this issue will be provided.

Basically, Yahya Harahap states that the most important principle in KUHAP is legality principle. ${ }^{50}$ It is emphasized in the consideration (a) on the KUHAP which states that Indonesia based on Pancasila and Constitution shall protect human rights and shall provide equal treatment between citizens. ${ }^{51}$ Yahya Harahap states that the consideration above implies legality principles based on rule of law where all conducts of law enforcement shall be based on legislations. ${ }^{52}$ This is strengthened by Article 3 of KUHAP which states that all means and procedures shall be based on the
Code..$^{53}$ It can be concluded that all conducts and procedures of law enforcements shall be based on legislations. It can be clearly stated that the prosecution conducted by KPK in money laundering case is not regulated in any legislations.

However, the question is whether KPK has to deliver the dossier of the investigation in money laundering cases to public prosecutor. It is complex to answer that question because Article 6 (c) of the Law on KPK rules that investigation and prosecution is the authority of KPK in one institution. In sort, there is also no regulation regarding how the prosecution shall be conducted, if the investigation done by KPK. In this situation, there are several interpretations in practice.

In the practice, there are several money laundering cases prosecuted by KPK in Corruption Court. Wa Ode's Case is a good example where money laundering case is brought by KPK because the corruption and money laundering are combined in one indictment. ${ }^{54}$ However, in that case the lawyer and also the judges do not pay attention to the authority of the KPK to prosecute money laundering. Conversely, in Lutfi Hasan Ishaaq's Case, two ad-hoc judges provided dissenting opinions regarding the authority of KPK to prosecute money laundering. ${ }^{55}$ Both judges considered that implicitly the Law on Money Laundering only authorizes public prosecutor to conduct prosecution on money laundering based on Article 72 of the Law. ${ }^{56}$

Based on the discussion, it can be concluded that eradication corruption system is not perfect. There is no complete

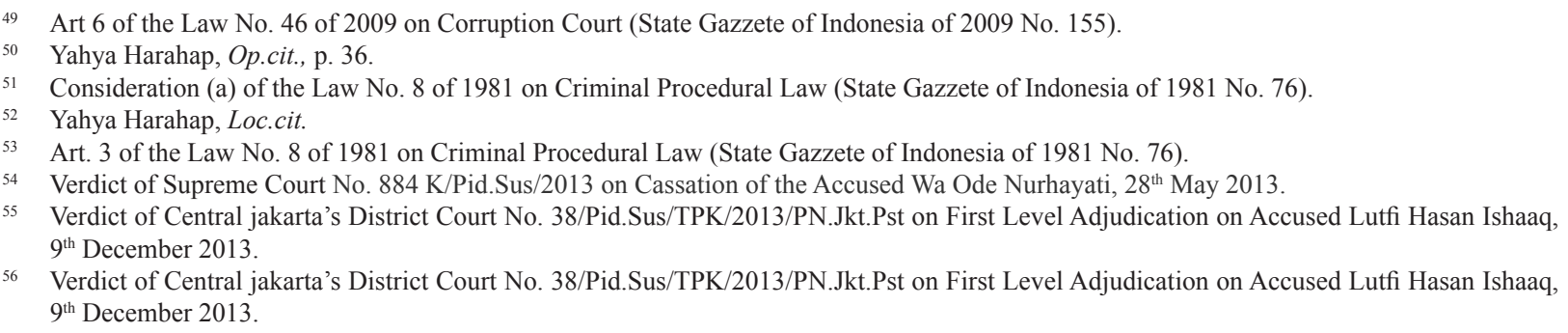


regulation regarding the prosecution of Money Laundering. The Law on KPK has given the specific authority of KPK. The Law on Money Laundering, then, expands the authority of KPK to investigate money laundering in corruption. Moreover, Corruption Court has the authority to adjudicate corruption and money laundering in corruption. However, there is no regulation how KPK may prosecute money laundering in corruption. Therefore, it is important to amend the related legislations to provide that authority.

\section{The Reform of Legislation Regarding} The Prosecution on Money Laundering in

\section{Corruption}

As discussed above, there is the absence of legislation regarding the authority to prosecute money laundering. However, based on the practice, this authority is particularly important for corruption eradication system. It is also related to the procedural principle which is quick, simple, and less-expensive. Considering the legality principle, it is a must to formulate the amendment of legislations regarding to the prosecution. To provide best formulation, this chapter will be provided by the discussion on money laundering eradication in several countries and also money laundering in UNCAC.

In anglo saxon system generally, the prosecutors and polices have different function, but the relationship between them is particularly strong. ${ }^{57}$ It is strong because the investigator shall report the prosecutor since the beginning of the investigation and prosecutor may instruct investigators in investigations. ${ }^{58}$ That concept is, at least, implemented in states which were occupied by British, such as, Australia, Malaysia, and Singapore. That concept shows how crucial the prosecutor is. It is similar to Anglo American where prosecutors have strong influence in criminal justice system. ${ }^{59}$ Prosecutor has the authority to continue or stop the case and in big cases like premeditated murder, Prosecutors have authority to investigate. ${ }^{60}$ It is slightly different with Indonesia. In Indonesia Prosecutors may only prosecute, but Article 30 (3) of the Law on General Attorney states that Prosecutors may conduct additional investigation. ${ }^{61}$ However, the functional differentiation principle is strongly introduced by KUHP, so that the authority of prosecutors is not mixed with investigators.

The better comparison can be achieved by the comparison on states that have anti-corruption institution. In Singapore Corruption Practices Investigation Bureau (CPIB) is established as the independent body to eradicate corruption in Singapore. ${ }^{62}$ As the special body to investigate corruption, the prosecution authority is still given to Attorney General Chamber. ${ }^{63}$ In Singapore, it can be seen that the prosecution is still authorized only to General Attorney. The similar regulation can also be seen in Malaysia. Anti-Corruption Commission in Malaysia a.k.a Badan Pencegah Rasuah (BPR) is established to eradicate corruption in Malaysia. ${ }^{64}$ Basically, BPR has the authority to prosecute, but that authority shall be permitted by Malaysian General Attorney. ${ }^{65}$ To emphasize, it is clearly shown that BPR in Malaysia has no power in prosecution. Moreover, the similar legislation can be seen in Australia. The establishment of Independent Commission Against Corruption 1988 in Australia aims to eradicate corruption in Australia ${ }^{66}$ In the function and authority sections, the authority of

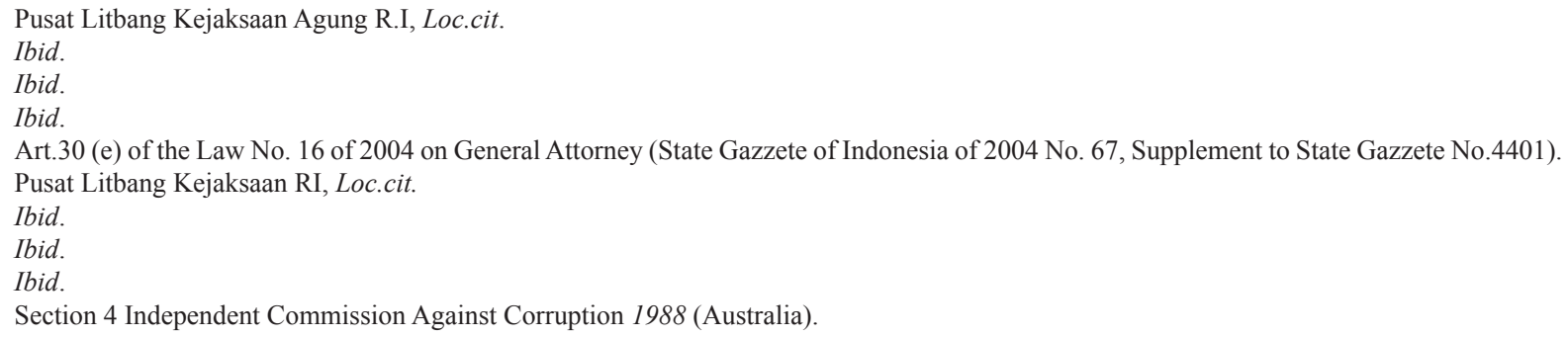


ICAC is only to investigate, not to prosecute. ${ }^{67}$ It can be simply concluded that in the comparison of those countries, the authority of prosecution is not given to anti-corruption commission.

Those results can be a consideration to separate investigation and prosecution, but it shall be understood that the unification of investigation and prosecution in KPK is particularly required. The condition of Corruption in Indonesia and those countries is different. It is supported by the consideration (b) of the Law on KPK which states that Government's institution is no longer effective to conduct corruption eradication system, so that KPK is required to be established. ${ }^{68}$ Those existing institutions are Polices and Prosecutors. The rank of corruption of those institutions is high so that the prosecution authority is particularly difficult, if it is fully given only to Prosecutors. Therefore, the Law on KPK provides the authority of KPK to prosecute corruption cases. This is the exception of functional differentiation principle. Since corruption is extraordinary crime, such exception is necessary.

To have a deep analysis, the discussion on money laundering and UNCAC is required to be delivered in this research. Basically, the basis of UNCAC is to harmonize the eradication of corruption and other relate crimes. ${ }^{69}$ Then, Article 14 of the UNCAC states that all state parties shall have regulation on money laundering. ${ }^{70}$ It implies that money laundering and corruption shall be regulated in one unified legislation so that there is no conflict of law in the future.

Basically, in corruption eradication system, there are some overlapping rules between Money Laundering and Corruption. The Law on KPK authorizes KPK to conduct investigation and prosecution for particular corruption cases. Then, the Law on Money Laundering authorizes the investigator of predicate crime to conduct investigation on money laundering. These regulations are inefficient and complex. It can be viable, if the law on KPK authorizes the KPK to investigate and prosecute corruption and money laundering in corruption. This is necessary because corruption is a extraordinary-special crime. It requires a comprehensive regulation. It is the same as regulated in the Law on Corruption Court. It adjudicates corruption and money laundering in corruption. Then, the authority of KPK in the Law on KPK shall be widened.

Therefore, to establish a harmonized corruption eradication system, there shall be a reform in corruption and money laundering laws. The law reform shall create the integrated corruption eradication system. There are several ways to harmonize the corruption eradication system.

Firstly, it is particularly required to regulated money laundering in the Law on Corruption. Before discussing the procedural law, the substantive law is crucial. Money laundering in corruption is more significant comparing to money laundering in other crimes. Therefore, it is important to regulated money laundering in corruption in the Law on Corruption. It follows the guideline of UNCAC which recommends the unification of money laundering and corruption in one codified legislation. This unification is necessary to reduce the overlapping legislation. This has been done in several legislations, such as the Law No. 35 of 2009 on Narcotics and the Law No. 18 of 2013 on Forest Destruction. In those legislations, money laundering is independently regulated, if it is committed after committing Narcotics crime or forest destruction. This is done to optimize the harmonization of Money Laundering and its predicate crime. As stated by UNCAC, money laundering has strong relationship with corruption, the unification of money laundering and corruption is necessary. Then, the law enforcement of corruption and money laundering can be harmonized.

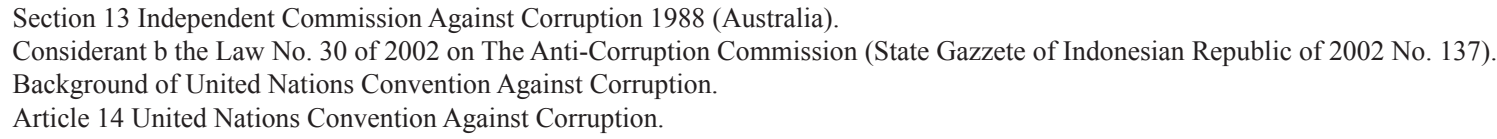


Secondly, it is important to authorize KPK in the prosecution on money laundering in corruption. Based on the discussion above, it is a need to give KPK the Authority. If KPK is authorized to prosecute, the corruption and money laundering case will be made in one indictment without separating the case. Article 141 of KUHAP states that if the cases have relationship, it is better to combine the cases in one indictment. ${ }^{71}$ It is in line with the principle of simple, cheap, and quick adjudication as stated in KUHAP. If KPK cannot prosecute money laundering in corruption, so the KPK investigator may deliver the corruption case to KPK prosecutor and the money laundering case to Public Prosecutor. Such process absolutely requires cost and energy and the decision of such case will be complex. Moreover, asset recovery as the goal of the Goal on Corruption can never be optimized without this authority because the KPK prosecutor may not optimally trace the proceed of corruption which is disguised by money laundering handled by another prosecutor. Hence, the authority of KPK to prosecute is crucial and necessary.

Furthermore, that authority shall be regulated under the Law on KPK because the Law on KPK is more specific than the Law on Money Laundering. Money laundering can be done in many crimes, including corruption so that money laundering law is a lot more general than the Law on KPK. Hence, it is crystal clear that the authority of KPK in prosecution money laundering shall be regulated under the Law on KPK. It is theoretically similar with the competence of corruption court which is regulated specifically in the Law on Corruption Court. This means that the Law on KPK shall be amended to regulate the prosecution by KPK on money laundering.

In short, there shall be the amendment of the law on corruption in the substantive matter and the law on KPK in the procedural matters. The reform of the Law on Corruption is important to regulate specific money laundering in corruption. Then, to strengthen the regulation, the Law on KPK shall also be regulated to regulate the authority of KPK to prosecute money laundering in corruption. These reforms are particularly required to provide the integration eradication system in Indonesia.

\section{Conclusion}

It can be stated that there is incomplete regulation on the prosecution on money laundering in corruption. In investigation on money laundering case, it is sufficiently clear that the investigator of predicate crime is the investigator of money laundering case. Hence, KPK may investigate money laundering in corruption. Moreover, in adjudication process, it is also clearly stated that Corruption Court also shall adjudicate money laundering in corruption. However, there is lack of regulation in prosecution of money laundering. KPK may prosecute corruption, but it cannot prosecute money laundering in corruption. Although there is no regulation, in practices, there are several cases where KPK conducted the prosecution on money laundering. However, such practices are theoretically wrong. The authority without clear regulation in criminal procedural law is illegal. But, the cases showed that KPK shall have the authority to prosecute money laundering. Based on that, it can be concluded that the prosecution authority on money laundering shall be given to KPK.

To cope with the absence of regulation, there is a need to reformulate legislations on money laundering and corruption. There are two ways to do that. Firstly, money laundering in corruption shall be regulated specifically on the Law on Corruption so that money laundering in corruption will be deemed as one of types of corruption. Secondly, the authority of KPK shall be widened to add the prosecution on money laundering. It is important to regulate that authority in the Law on KPK.

Furthermore, there are several recom- 
mendations to establish the integrated corruption eradication system. Firstly, in the absence of regulations, the law enforcement officials shall have proper considerations in handling money laundering in corruption cases. One of the proper considerations is that if KPK conducted the investigation on money laundering, KPK shall be able to conduct the prosecution. The judges shall establish a decisions which authorizes KPK to conduct that authority. Secondly, in order to have a legal certainty, it is particularly required to regulate that KPK has the authority to prosecute money laundering in corruption. Since the basic principle of criminal law and criminal procedural law is legality principle, the authority shall be written in any legislation. Thirdly, in order to have perfect regulations, it is a need to have integrated law enforcement in corruption eradication system. Polices, prosecutors, and KPK shall have one main purposes and shall be able to cooperate in eradicating corruption. The conflict between institutions shall be reduced and abolished in order to have better corruption eradication system.

\section{REFERENCES}

\section{A. Books}

Amrullah, M. Arief, 2004, Tindak Pidana Pencucian Uang, Bayu Media, Malang.

Atmasasmita, Romli, 2010, Sistem Peradilan Pidana Kontemporer, Kencana, Jakarta.

Asshiddiqie, Jimly, 2007, Pokok-Pokok Hukum Tata Negara, Pasca Reformasi, Kelompok Gramedia, Jakarta.

Chazawi, Adami, 2003, Hukum Pidana Materiil dan Formil Korupsi di Indonesia, Bayumedia, Jakarta.

Djaja, Ermansjah, 2008, Memberantas Korupsi bersama KPK, Sinar Grafika, Jakarta.

Friedman, Lawrence M., 2001, Hukum Amerika Sebuah Pengantar Penerjemah Wishnu Basuki, Tatanusa, Jakarta.

Hamzah, Andi, 2006, Pemberantasan Korupsi Melalui Hukum Pidana Nasional dan Internasional, Grafindo persada, Jakarta.

Harahap, Yahya, 2002, Pembahasan Permasalahan dan Penerapan KUHAP: Penyidikan dan Penuntutan, Ed.2, Cet. 4, Sinar Grafika, Jakarta.

Husein, Harun M., 1991, Penyidikan dan Penuntutan Dalam Proses Pidana, Rineka Cipta, Jakarta.

Lembaga Administrasi Negara Pusat Kajian Administrasi Internasiona, 2007, Strategi Penanganan Korupsi di Negara-negara Asia
Pasifik, Jakarta.

Muladi, 1995, Kapita Selekta Sistem Peradilan Pidana, Badan Penerbit Undip, Semarang.

Packer, Hebert L., 1973, The Limits of Criminal Sanction, Stanford University Press, Stanford.

Priyanto, et al., 2007, Rezim Anti Pencucian Uang Indonesia: Perjalanan 5 Tahun, PPATK, Jakarta.

Sudarso, Boesono, 2009, Latar Belakang Sejarah dan Kultural Korupsi di Indonesia, Universitas Indonesia, Jakarta.

Sudarto, 1985, Kapita Selekta Hukum Pidana, Alumni, Bandung.

Suyatno. 2005, Korupsi, Kolusi, Dan Nepotisme, Pustaka Sinar Harapan, Jakarta.

Wijowasito, 1999, Kamus Umum Belanda Indonesia, Ikhtiar baru, Jakarta.

\section{B. Government Regulation}

The Law No. 8 of 1981 on Criminal Procedural Law (State Gazzete of Indonesia of 1981 No. 76). The Law No. 31 of 1999 on Corruption Eradication (State Gazzete of 1999 No. 140,Supplement to State Gazzete No.3874).

The Law No. 30 of 2002 on The Anti-Corruption Commission (State Gazzete of Indonesian Republic of 2002 No. 137, Supplement to State Gazzete No.4250). 
The Law No. 16 of 2004 on General Attorney (State Gazzete of Indonesia of 2004 No. 67, Supplement to State Gazzete No.4401).

The Law No. 46 of 2009 on Corruption Court (State Gazzete of Indonesia of 2009 No. 155, Supplement to State Gazzete No.5074).

The Law No. 8 of 2010 on Prevention and Eradication of Money Laundering (State Gazzete of 2010 No. 122, Supplement to State Gazzete No.5164).

United Nations Convention Against Corruption.

\section{Court Decision}

Verdict of Supreme Court No. 884 K/Pid.Sus/2013 on Cassation of the Accused Wa Ode Nurhayati, $28^{\text {th }}$ May 2013.

Verdict of Central jakarta's District Court No. 38/ Pid.Sus/TPK/2013/PN.Jkt.Pst on First Level
Adjudication on Accused Lutfi Hasan Ishaaq, $9^{\text {th }}$ December 2013.

\section{Internet Articles}

Billy Steel, "Money Laundering-A Brief History", http://www.laundryman.unet.com, accessed on 21 November 2014.

Pusat Litbang Kejaksaan Agung R.I, "Studi tentang Implementasi Kekuasaan Penuntutan di Negara Hukum Indonesia", http:// www.kejaksaan.go.id/unit_kejaksaan.

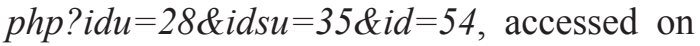
30 October 2014.

\section{E. Miscellaneous}

Yunus Husein, "KPK Berwenang Menuntut TPPU", Seputar Indonesia, 16 January 2014. 